\title{
O ANALIZĂ SUCCINTĂ A ETICII ORFICE ÎNTR-O PERSPECTIVĂ CREŞTINĂ
}

\author{
Laurenţiu-Sorin Ormenişan*
}

\begin{abstract}
The Orphism is considered to be the most important current of the $6^{\text {th }}$ century BC, which influenced the Greek culture, because it brings a renewal in the attitude towards life and death. It was also the best known current of the epoch, also because it was the least defective. It tried to reveal ,a different life", to help people discover their life purpose, which is to be immortal as gods and to live together. Orpheus is the founder of Orphism, and is reckoned as the father of the Panhellenic faith. He gave to the Greeks the hope for a better and more important life on the other world by caring for the soul. Orpheus was able to cancel the distance between humans and gods. The orphism sought to be a spiritual exercise without which culture risks to become just a sterile and misunderstood practice.
\end{abstract}

Keywords: orphic way of life, Orpheus, Dionysos, death, inner discipline, immortality, teletai, soul, reborn, destiny

\section{Introducere}

Orfismul este considerat cel mai însemnat curent al secolului al VI- lea î.d.Hr., care a marcat şi influențat cultura elenă, datorită înnoirii pe care o aduce, prin întreaga raportare la moarte şi viață, prin dobândirea unei noi optici şi viziuni asupra problemelor existențiale. Orfismul este cel mai cunoscut curent din această perioadă, tocmai pentru că este cel mai puțin lacunar, iar, pe de altă parte, orfismul ar continua vechile tradiții religioase elene, însă cu anumite împrumuturi din alte culturi şi religii. Orfismul a încercat să

\footnotetext{
* PhD candidate, at University „1 Decembrie 1918” Alba Iulia, România
} 
fie ,o alt fel de viață" ${ }^{\prime}$, o atitudine care să îmblânzească asprimea spiritului grec. Orfismul este o doctrină ale cărei elemente, deşi sunt dispersate, s-au adunat şi s-au păstrat sub acelaşi nume.

Orfeu este socotit a fi părintele credinței panelenice, care a descoperit oamenilor doctrina misterelor şi a ritualurilor sacre. Este considerat întemeietorul ştiințelor sacre şi a celor profane, având în acelaşi timp contribuții în cadrul religiei şi artelor ${ }^{2}$. Acest lucru este recunoscut nu doar de către marii maeştrii spirituali ai antichității elene, ci şi de unii părinţi creştini care au cunoscut cultura elenă. Orfeu $^{3}$ a izbutit să „,̂mblânzească” sufletele şi instinctele omului

${ }^{1}$ W. K. C. Guthrie, Orpheus and the greek religion, Second edition, London, 1952 , p. 38.

${ }^{2}$ George R.S. Mead, Orpheus, Second edition, Kessinger Publishing, 2010, p. 5.

${ }^{3}$ Pentru mai multe detalii asupra orfismului a se vedea lucrările: Gernet Louis et André Boulanger, Le Génie grec dans la religion, Paris, 1932; Jane Ellen Harrison, Themis. A study of a social origins of Greek religion, Cambridge, 1927; Martin P. Nilsson, A History of Greek Religion, translate to sweden by F.J. Fielden, second edition Oxford, 1949 - en français Les croyances religieuses de la Grèce antique, Paris, 1955; Walter Burkert, Griechische Relihion der archaischen und klassischen Epoche, Stuttgart, 1977, translate in englesh with name: Greek Religion, Oxford, 1985; Francis Vian, La religion à l'époque archaïque et classique, în Histoire des religion (Enciclopedia Pleiade) tom I, publicată sub coordonarea lui Henri -Charles Puech, Paris, 1970, pp. 489-577; Walter Burkert, Structure and History in Greek Mythology and Ritual, Berkeley-Los Angeles, 1979; Marcel Detienne, L'inventation de la mythologie, Paris, 1981; Lewis R. Farnell, The Cults of the Greek States, V tome, Oxford, 1896-1909; Parke H. W., Festivals of the Atenians, Londra, 1977; Jean Rudhardt, Notions foundamentales de la pensée religieuse et actes constitutifs du culte dans la Grèce classique, Geneva, 1958; Marie Delacourt, L'Oracle de Delphes, Nouveaux edition, Paris, 1981; Parke H.W., and Wormell D.W., The Delphic Oracle, Oxford, 1956; Walter Burkert, Ancient Mistery Cults, Cambridge-London, 1987; Marcel Detienne, L'Écriture d'Orphée, Paris, 1989; Idem, Dionysos mis à mort, Paris, 1977; Maria Daraki, Dionysos, Paris, 1985; Henri Jeanmaire, Dionysos: Histoire du culte de Bacchus, Paris, 1951; Karl Kerényi, Dionysos, Archetypal Image of Indestructible Life, London, 1976; George E. Mylonas, Eleusis and the Eleusisan Mysteries, Priceton, 1961; Walter F. Otto, Dionysos, Mythos und Kultus, Frankfurt, 1933, traduit en 
primitiv şi să întoarcă apucăturile neîmblânzite, de la războaie şi vărsări de sânge la frăţietate şi pace. El i-a învățat pe oameni însemnătatea blândeții, tihna şi optimismul. Tot lui îi revine meritul de a fi cel care descoperă sau îi învață pe oameni scrierea. Este socotit precursorul artei poetice, dar şi un începător în scrierile literare. De asemenea, îi sunt atribuite diferite roluri principale în domeniul medicinei, dar şi în mai multe domenii ale ştiinței. Cea mai flatantă descriere a zeului-cântăreț din liră am găsit-o într-o traducere a filosofului Noica, care îl descrie astfel:,,un magician al logos-ului, sub fascinația cântecului său durata însăşi stă în loc. Ascultându-i cuvintele ritmate de liră, Tantal îşi uită setea şi foamea. Danaidele încetează să mai umple butoiul fără fund, Sisif vede piatra încremenită în creştetul colinei, roata lui Ixion se opreşte. Unor asemenea ființe, pe care nimic nu le mai poate vindeca de durerea existenței în timp, Orfeu le aduce eliberarea. Din simple incantaţii, puse în joc cu o adevărată tehnică de terapeut, obține iată, miracolul: pe albia duratei se decantează o clipă, una singură, cea a eternității. În fapt nimic, altceva decât obişnuitul procedeu de ieşire din timp, decât simpla anulare a distanței om-divinitate"4. Toată prezentarea cosmogoniei orfice nu este altceva decât o anulare a duratei prezente şi întoarcerea către starea primordială. Regimul de viaţă orfic urmărea tocmai acest lucru: să triumfe în oamenii născuţi din cenuşă elementul divin asupra celui titanic. Un alt caz asemănător de anulare a spaţiului dintre om şi divin este cel al lui Prometeu care, prin furtul focului zeilor, deschide o lume a creației, iar Orfeu prin terapie ezoterică ajunge la ieşirea din timp. Primul a angajat omenirea pe

français Patrick Levy, Dionysos, Le mithe et le culte, Paris, 1969; W.K.C. Guthrie, Epithets in the orphic hymns, in „The Classical review”, Vol. 44, nr. 6, december, 1930, pp. 216-221; Idem, Orpheus and the greek religion, Second edition, London, 1952; George R.S. Mead, Orpheus, Second edition, Kessinger Publishing, 2010;

4 ***, Fragmentele presocraticilor, Traducere integrală după ediția DielsKranz cu introducere şi note de Simina Noica şi Constantin Noica, Volumul I, Editura Junimea, Iaşi, 1974, p. 21. 
făgaşul unei progres tehnic, cel de-al doilea către valorile spirituale perene ale poporului grec.

\section{O scurtă demarcare a orfismului}

Orfismul ocupă un loc intermediar, atât între diferite religii şi mişcări filosofice, cât şi între anumite grupuri cu acțiuni asemănătoare acestei secte. Orfismul are ca fundament religios aceiaşi zei ca şi cei menționați în scrierile lui Homer şi Hesiod. Dar, în timp ce oamenii şi zeii sunt prezentaţi ca nişte categorii foarte bine separate, tocmai pentru că cei dintâi nu pot fi nemuritori, pentru orfici învățătura a fost aceea că omul poate să ajungă să dobândească statutul de persoană divină, să devină şi el la rândul lui zeu. Cu toate acestea, orficii au respins în cultul lor ritualurile sângeroase care erau caracteristice cultului bahic. Cultul orfic şi cel pitagoreic au multe crezuri comune ca: metempsihoza, dualismul dintre trup şi suflet, purificările şi felul închis al asociației. De asemenea, orfismul împărtăşeşte cu misterele Eleusiene atât Mitul lui Demeter şi Persephone, credința în mântuirea sufletului, cât şi ritualul inițiatic. Cultul eleusian a devenit într-un scurt timp de la întemeiere un cult stabil, adepții fiind grupați în jurul unui sanctuar cu slujitori, iar toate acestea controlate de către anumite familii influente din cetăți, în timp ce orfismul era lipsit de sanctuare şi fără o preoție stabilă. Orfismul a coincis cu diferite idei despre divinitate, dezvoltate de autori precum Pindar, Heraclit şi Eschil, care îl susţineau ca şi creator al universului pe Zeus ${ }^{5}$. Însă, în mai multe texte orfice sunt incluse mai multe caracteristici aparținând religiilor orientale, cum ar fi declarațiile de pe frunzele de aur, similare cu cele ale „cărții morților" la egipteni.

Orfismul a fost un fenomen complex. El s-a prelungit şi a îmbrățişat o lungă perioadă, plină de metamorfoze, din secolul al VIlea î.d.Hr., până la exegeza neoplatonică din Alexandria din timpul

\footnotetext{
$5 * * *$, Encyclopedia of religion, Second edition, Tome 10, New York, 2005, pp. 457-458.
} 
lui Olympiodorus ${ }^{6}$ din secolul al VI-lea d.Hr. De altfel, orfismul a cuprins trei tipuri relativ autonome de fenomene religioase. Astfel, primul dintre acestea, a fost reprezentat de tradițiile care aminteau de naşterea, viaţa, coborârea în infern şi moartea tragică a lui Orfeu. Al doilea este cel al unei literaturi în care sunt cuprinse scrieri atribuite lui Orfeu, care dau, de asemenea, mai multe contururi teogoniei orfice. În cel de-al treilea aspect, orfismul includea ca şi grupare o serie de practici şi norme care trebuiau respectate de către cei care şiau asumat $\mathrm{o}$ astfel de viață.

În ciuda dovezilor tot mai multe despre un orfism ca şi mişcare religioasă, savanții precum Luc Brisson ${ }^{7}$ sunt sceptici în ce priveşte existența unei religii cu un caracter ritualic specific. Claude Calame ${ }^{8}$ şi-a exprimat mult mai moderat, însă totuşi sceptic puctul de vedere, afirmând că multe credințe care susțin nemurirea sufletului, metempsihoza, ritualuri ca teletai, dar şi atitudini personale ca vegetrarianismul şi purificările, par să se fi împletit între ele. În acest fel, s-a înțeles că este mai bine să aparțină aceleiaşi mişcări, decât ca şi mici grupuri cu convingeri separate. Nu trebuie să uităm însă că modul eterogen în care s-au raportat la religie este un specific al grecilor.

Există posibilitatea ca mitul să se fi întemeiat doar pe ciclicitatea vegetaţiei, prin constatarea morţii şi renaşterii vegetaţiei în fiecare an. Într-o accepțiune alegorică „Dionysos dezmembrat ar fi viţa de vie; Titanii ar fi culegătorii care rup şi strivesc strugurii înainte de a fierbe vinul pentru a-l îmbunătăți (lenos, teasc mai are şi înțelesul de coşciug); Demeter - pământul- fecundată de Zeus ploaia, cerul- pentru a-i da naştere lui Dionysos - vița de vie, adună mădularele viței şi o face să renască în fiecare an. Dionysos orficul

\footnotetext{
${ }^{6}$ Ibidem, p. 458.

${ }^{7}$ A se vedea lucrările: Luc Brisson, Orphéé et l'orphisme dans l'antiquité gréco-roumaine, Aldreshot, U.K., 1995; Idem, Damascius et l'Orphisme, în Orphisme et Orphée, Droz, Geneva, 1991;

8 Claude Calame, Philippe Borgeaud, Andre Hurst, L'Orphisme et ses écritures: nouvelles recherches, „Revue de l'histoire des religions”, nr. 219, 2002, pp.379-515;
} 
nu este o divinitate agrară, ci un copil zeu, a cărui inițiere coincide cu începutul unui nou sfârşit cosmic",9.

\section{Stadiul actual al cercetării}

Atenția asupra cercetării orfismului reapare începând cu secolul al XIX-lea, prin monumentala lucrare a lui Augustus Christian Lobeck „Aglaophamus” din 1829, în care a adunat şi a comentat materiale din literatura şi religia orfică. În opoziție cu aceasta se află monumentala lucrare a lui Georg F. Creuzer din anii 1810-1812, numită „Symbolik und Mythologie der alten Völker", care aduce o mare înțelegere asupra mistificării. Până la această dată, cercetările din acest domeniu sunt foarte vagi. Cercetările următoare încep să prindă tot mai mult nuanțe şi păreri diferite. Astfel, autori precum Jane Ellen Harrison şi Albrecht Dieterich susțin ferm că orfismul a fost o adevărată ,biserică”, care a avut o mare influență chiar şi asupra filosofiei din acea perioadă. Alți cercetători din acest domeniu, precum Vittorio Macchioro şi Robert Eisler au argumentat creştinismul pe o derivație a orfismului. În urma acestor excese apare lucrarea lui Ulrich von Wilamowitz-Moellendorff, în jurul anilor 1930, ca o reacție critică, urmată mai apoi de cele ale lui Ivan M. Linforth, E. R. Dodds şi alții,care susţin prezența ofismului încă din perioada de dinaintea elenismului clasic. Această linie de cercetare, care a dominat până înspre anii 1970, susținea că orfismul nu este nimic mai mult decât o serie de interpretări ale lui Herodot şi ale unor filosofi neoplatonici, dar şi ale unor istorici moderni pasionați de misterele păgâne ${ }^{10}$. O lucrare de dată mai recentă este lucrarea lui Reynal Sorel, ,Orphée et l'orphisme”din 1995, care prezintă un punct de vedere echilibrat, dar bine documentat şi dinamic.

În preajma anilor '70 sunt descoperite mai multe obiecte care aparţin culturii orfice şi asurpa cărora au apărut diferite studii. Voi

\footnotetext{
${ }^{9}$ Reynal Sorel, Orphée et l'orphisme, Presses Universitaires de France, Paris, 1995; pp. 97-98.

$10 * * *$, Encyclopedia ...op. cit., p. 458.
} 
menţiona doar câteva dintre acestea. În 1962 a fost descoperit la Derveni, lângă Tesalonic, o „carte orfică” datând aproximativ din anul 330 î.d.Hr. şi care a fost scrisă în jurul anilor 400 î.d.Hr., care prezintă un comentariu filosofic asupra teogoniei şi cosmogoniei orfice, fără a avea influențe platonice. O altă descoperire, de această dată din bazinul Mării Negre, are loc în 1978, când un grup de cercetători au descoperit trei mici tablete de os în localitatea Olbia ${ }^{11}$. Aceste tablete atestă existența încă din secolul V î.d.Hr. a unui grup numit orfic, care avea un mare devotament faţă de Dionysos ${ }^{12}$ şi care are o valoare mai mult eshatologică. Pe nişte plăcuțe de os erau scrise alăturat Dionysos Orfikoi urmate de cuvintele: $\beta 10 \varsigma \tau \alpha v \alpha \theta$ os $\beta 10 \varsigma$ (viaţă moarte viață), iar această denumire reprezintă mai mult un amestec enigmatic decât o afirmație sigură. Însă, este posibil ca această inscripție să fie doar o mărturie a unei comunități restrânse. Mai există o serie de descoperiri din Sudul Italiei şi din Sicilia care atestă mărturiile şi influențele orfismului de pe aceste meleaguri. În linii mari, toate aceste studii care vorbesc despre obiectele descoperite, nu depăşesc prea multe spațiul tehnic şi părerile trunchiate asupra cultului orfic.

\section{Orfeu şi orfism - origini}

Pentru acest început, este important să facem o mică dar necesară diferență, între Orfeu şi adepții cultului orfic. Există diferite păreri care susțin primatul unuia față de celălalt. Însă, cei care au ales calea orfică au preluat titulatura celebrului cântăreț pentru a căpăta o mai mare rezonanță. Istoricitatea lui Orfeu este pusă la îndoială de majoritatea cercetătorilor. (este posibil ca de la numele de „însingurați” orphoi să fi fost născocită o legendă cu Orfeu). Asupra patriei lui Orfeu, există câteva păreri diferite. $O$ parte dintre

\footnotetext{
${ }^{11}$ Pentru mai multe detalii a se vedea lucrările: Laurent Dubois, Inscriptions grecques dialectales d'Olbia du Pont, Geneva, 1996, pp. 154-155; Leonid Zhmud, Orphism and grafitti from Olbia, in Hermes nr.120, 1992, pp. 159-168; $12 * * *$, Encyclopedia ...op. cit., p. 458.
} 
cercetători susțin că locul de baştină al lui Orfeu ar fi Tracia ${ }^{13}$, însă epoca în care a trăit rămâne o enigmă, tocmai pentru că există mărturii care îl menționează chiar şi înaintea lui Homer ${ }^{14}$.

André Boulanger, autorul lucrării „Orphee: rapports de l'orphisme et du christianisme" ${ }^{\text {, }}$, a cărui lucrare nu am menționat-o în actualitatea cercetării, prezintă câteva puncte principale ale orfismului şi câteva rapoarte între cultul orfic şi cel creştin. Acesta susține că orfismul ar fi apărut în Magna Grecia, deoarece există multe asemănări între partea religioasă a pitagoreismului şi orfismul inițial. Această înrudire ar fi fost atât de mare, încât se crede că ar fi având nu doar o origine comună, ci ar fi existat o perioadă nedeterminată în care ar fi fost o singură religie orfico-pitagoreică ${ }^{16}$. De asemenea, acelaşi autor consideră că trăsăturile definitorii ale orfismului precum conştiința păcatului, nevoia de purificare şi răscumpărare, toate acestea nu au fost semnalate la traci ${ }^{17}$. Originea tracă a lui Orfeu a fost susținută de Strabon şi Plutarh, apoi reluată de E. Rohde în Psyché, însă E. Mass şi P. Perdrizet, susțin contrariul.

După o altă părere, larg răspândită şi susținută de cercetătorul S. Reinach ${ }^{18}$, Orfeu ar fi fost o zeitate htonică de origine tracă, devenind cunoscut în sudul Italiei şi Sicilia ca un cântăreț divin care, prin puterea lirei şi a cântecelor, subjuga natura dar, în acelaşi timp,

${ }^{13}$ W. K. C. Guthrie, op. cit., pp. 36-37; Karl Robert, Die griechische Uddnsage I, Berlin, 1920, pp. 397-398: ,pe tot cursul întregii antichități a fost întotdeauna considerat a fi născut în Tracia”.

${ }^{14}$ Asupra complexității personajului, făcut de erudiți, care erau de părere că este vorba chiar de mai multe personaje, a se vedea: J. Naodou, Protohistoire, Histoire Universelle, Enciclopedie de la Pleiade, 1956, p. 91; W. K. C. Guthrie, op. cit., pp. 48-52.

${ }^{15}$ André Boulanger, Orphee: rapports de l'orphisme et du christianisme, Paris, 1925.

${ }_{17}^{16}$ Ibidem, p. 19.

${ }^{17}$ Ibidem, p. 47.

${ }^{18}$ A se vedea opera lui S. Reinach: Orpheus, edition huit, Paris, 1918, p. 121; şi articolele „,Zagreus le serpent connu”, „La mort d'Orphée”, „Une formule orphique”, „Morale orphique et morale chrétienne”. 
dezvăluia oamenilor originea zeilor şi a oamenilor. Este posibil ca importanța lui Orfeu să fi fost de rezonanță şi acesta să fie asemănat cu orice cult misteric, pentru că în cadrul lor, el le descoperea oamenilor adevărata lor origine.

Este nedrept să socotim cult orfic toate cultele care care au încercat să reînvie sentimentul religios din secolul al VI-lea î.d.Hr., care s-au perindat prin Grecia Magna, iar pe lângă acest lucru, este nedrept să socotim tradiție orfică orice cult de reînniore spirituală sau morală din această perioadă. Pentru a înțelege orfismul, este important să-1 analizăm în starea lui primordială, aşa cum a fost întemeiat şi transmis primelor generații. Pe lângă acest lucru, trebuie să amintim că există un văl asupra orfismului, acesta fiind confundat adesea cu un cult al lui Dionysos infernal sau cu misterele bahice. Orfismul a fost considerat o religie imobilă care acoperă de multe ori realități foarte diverse. La început, orfismul a fost o „formă ascetică de viaţă religioasă, apoi o speculație"19. Acest lucru se datorează şi lipsei de documente asupra doctrinei şi a cultului, şi a relatărilor sărace din antichitate, scrierilor lui Herodot, Platon, Aristotel, Eudemos, etc., documentelor care s-au păstrat până astăzi şi care sunt de cele mai multe ori din perioada neoplatonică şi care vor să arate că poemele orfice sunt în conformitate cu învățătura lui Platon.

\section{Etapa de început a orfismului şi dezvoltarea acestuia}

Perioada din a doua jumătate a secolului al VI-lea î.d.Hr., oferea o atmosferă propice dezvoltării cultelor de mistere. Dezvoltarea cetăților-stat aduc cu ele o nobilime bine centrată asupra polisu-lui, în timp ce majoritatea oamenilor se luptă la marginea existenței într-o sărărie crâncenă. Pentru cei bogați, viața de huzur a dat naştere unui nelinişti morale, care şi-a găsit liniştea spirituală în apropierea de un cult-exotic al misterelor. Însă pentru marea masă a oamenilor, se simțea nevoia unei credințe noi în capacitatea de a face din această viață ceva pentru cealaltă. În asemenea împrejurări,

${ }^{19}$ André Boulanger, op. cit., p. 11. 
cultele de mistere au venit la timpul potrivit şi au fost îmbrățişate de toate masele de oameni Din punct de vedere politic, succederea tiraniilor şi izbucnirea multor revolte în cadrul polis-ului au adus şi acesteia nevoia de o stabilitate, iar pe un fond religios se credea că acest cult al misterelor ar putea stabili un sistem politic echilibrat. Astfel, şi puterea politică susținea diferitele culte de mistere, după cum menționează un secol mai târziu şi Pindar despre conducerea din Sicilia. În acest ținut coabitează în armonie atât cultele vechi agrare, cât şi cele din cadrul misterelor, dar şi culte provenite din Orient, din Creta şi, probabil, şi a unora egiptene. Au devenit deosebit de înfloritoare culte ale divinităţilor htoniene, precum, Kore-Persefona, Demeter, Dionysos, Hades, atât în Grecia cât şi în Italia şi Sicilia, după cum atestă săpăturile de la începutul secolului XX din sudul Italiei şi Sicilia ${ }^{20}$. În aceste sanctuare era venerată o divinitate feminină, socotită a fi protectoare a fecundității şi a celor morți, alături de fiul ei. Astfel, s-au născut asociaţii religioase numite "thiaze". Nu se cunosc multe detalii din cadrul acestor asociaţii, cert este că aveau ca scop asigurarea fericirii sufletului după moarte şi este posibil să fi avut doar un simplu rol funerar. Pentru majoritatea oamenilor care doreau să aibă o siguranță în fericirea pe lumea cealaltă, asociațiile au devenit repede centre puternice, care au influențat societatea prin numărul mare de adepți câştigați într-un timp relativ scurt. Prin contactul oamenilor din toate păturile sociale, aceste grupări au ajuns să accepte şi unele idei străine, care să satisfacă nevoile spirituale şi speranța în fericirea pe lumea cealaltă.

Membrii acestor asociații se supuneau de bunăvoie unor norme de viaţă ascetică, rigorile fiind urmate până şi asupra înhumării în locuri destinate exclusiv comunității. Pe postamentul acestei grupări se înalță o idee pesimistă asupra vieții, un sentiment acut dintre, zădărnicia omului şi a faptelor sale în contrast cu măreția ideilor şi a aspirațiilor sale. Încet dar sigur, se desprinde o idee care

\footnotetext{
${ }^{20}$ Asupra cultelor din Italia meridională a se vedea lucrarea: G. Gianelli, Culti e miti della Magna Grecia, Florența, 1924; iar asupra celor din Sicilia a se vedea Ciaceri, Culti e miti nella storia dell' antica Sicilia, Catania, 1911;
} 
prezintă o dihotomie a omului. Contradicția dintre faptele şi aspirațiile lui, au adus ideea dualismului care afirma că „ceva din lăuntrul omului" ${ }^{21}$ - sufletul este de origine divină, dar este înlănțuit în trupul de care trebuie să scape. Însă, prin diferite purificări şi practici austere de viață asupra trupului, credinciosul se va elibera şi va fi bine călăuzit în lumea subpământeană.

Doctrina acestei secte nu este întemeiată pe o simplă speculație, ea este legată de un „hieros logos”- un ansamblu de mituri care au în centrul acțiunii lor divinități care au influențat sau au format acest cult cum sunt Persefona, Dionysos, Kore și alții. Din hierogamia Persefonei cu Zeus, preschimbat într-un animal, s-a născut Dionysos, predestinat a fi ultimul zeu-rege printre oameni. Titanii, nişte ființe malefice, urmăresc copilul şi îl devorează, din această omofagie scăpând doar inima. Din acest organ. Zeus îl reînvie pe Dionysos, iar pe titani îi va trăsni. Din cenuşa acestor titani se vor naşte oamenii, care au în ei două elemente contradictorii, pe de o parte ,firea titanică” partea rea, întunecată şi războinică, iar pe de altă parte „firea divină”, pe care au dobândit-o prin omofagia devorării micii divinităţi.

După Otto Kern ${ }^{22}$, membrii acestei grupări şi-au primit numele de „orphoi" adică însingurați, datorită modului lor de viețuire, după cum şi Orfeu, după ce s-a întors din Hades, a rămas toată viața singur. Numele lui Orfeu este legat şi de alte legende cum ar fi „Argonautica”, în care are un rol important în restabilirea dreptății, astfel că Orfeu ajunge să fie recunoscut ca interpret al zeilor, iar mai apoi dobândeşte statutul de întemeietor al cultelor de mistere.

Mircea Eliade este de părere că orfismul şi pitagoreismul sau dezvoltat simultan, fiind o expresie a aceluiaşi Zeitgeist, deosebirea vizibilă fiind aceea că pitagoreismul s-a organizat ca o societate-sectă ,închisă” de tip ezoteric, promovând un sistem de educație complex, în care cunoaşterea avea o funcție atât existențială

${ }^{21}$ André Boulanger, op. cit., p. 22.

${ }^{22}$ Otto Kern, Orphichorum fragmenta, Berlin, 1922, pp. 16-19. 
cât şi soteriologică $\breve{2}^{23}$. Pitagoreicii au activat în viaţa politică, ocupând funcții de conducere în mai multe cetăți din Italia meridională. În schimb, orfismul a fost o mişcare concomitent înclinată spre marea masă a oamenilor, dar a sedus şi elitele vremii, însă fără o implicare în sfera politicului.

\section{Orfism versus homerism}

Oricât ar părea de slab conturată, imaginea orfismului rămâne într-un contrast vădit concepției homerice. Dacă pentru personajele epopeii lui Homer pofta de a trăi este cel mai înalt dar, totuşi, moartea este cea care sfârşeşte bunul cel mai mare al omului - viața, şi destinul sufletului îl va duce la o viață inconştientă şi umilitoare în lumea de dincolo. Pentru orfici, viaţa adevărată începe cu moartea ${ }^{24}$, natura sufletului fiind de origine divină, iar destinul acestuia fiind nemurirea sufletului ${ }^{25}$. Un alt contrast pregnant este acela al zeilor homerici, care par a fi nişte supraoameni antropomorfizaţi ${ }^{26}$ până la ridicol, fie a unor divinități difuze, care pare a tinde către un monoteism panteist. Orficii, în schimb, susțin omul pentru a deveni el însuşi un zeu. Pentru concepția homerică, acest lucru ar fi nu doar o nesăbuință, ci chiar o nebunie. Există în epopeea homerică câteva cazuri în care se acceptă o stare de fericire în lumea de dincolo, şi care corespunde cu disparițiile în insulele fericiților. Acest lucru se întâmplă şi cu Menelau, care este rudă cu Zeus, şi cu încă câțiva eroi care au murit în luptă. Toate aceste excepții au rolul de a întări regula. Pe parcusul vremii, tot mai mulți tineri se întrec în fapte de vitejie pentru a deveni eroi şi a scăpa de tărâmurile întunecate ale Hadesului, însă contrastul este mare vis-a-vis de orfici, la care cel care va trăi autentic credința va putea deveni eu zeu. Eroii epopeii

${ }^{23}$ Eliade M., Istoria credințelor şi ideilor religioase, ediția II, Volumele II, Traducere de Cezar Baltag, Editura Ştiințifică şi enciclopedică, Bucureşti, 1986, p. 191.

${ }^{24}$ André Boulanger, op. cit., p. 34.

${ }^{25}$ Geroge, R.S. Mead, op. cit., p. 18.

$26 * * *$, Encyclopedia...op. cit., p. 457. 
care au înrudire cu divinităţile sunt persoanele cele mai aproape de zei, iar legătura lor pare a fi lipsită de misticism, în contrast cu orfismul, care susține cu putere credința într-o judecată după moarte şi responsabilitatea individuală în fața unui tribunal. Însă, acest lucru nu anulează responsabilitatea față de clan, familie, grup, tocmai prin ideea păcatului originar.

\section{Comunitatea orfică}

Orficii nu formau, de obicei, comunități stabile. Fiind o religie care promitea mântuirea individuală, orfismul a ajuns la un moment dat să fie considerat periculos în societatea greacă, unde religia a fost un mijloc de integrare în polis. Homer a încercat să creeze un panelenism unitar, iar asupra acestei idei, orfismul aduce multe noutăți care fac să schimbe vechea structură. Însă, din lipsa de mişcare a organizației, ea nu a asigurat niciodată o alternativă de status-quo.

Comunitățile orfice stabile erau destul de puține, dacă este să tinem cont de cele câteva locaţii unde au fost descoperite documente, inclusiv cele de la Olbia şi probabil Cumae. În secolul al V-lea î.d.Hr. inscripția descoperită la Cumae interzicea celor care nu au avut o transă extatic- teletai- să fie îngropaţi în acel loc. Luând inscripția ca punct de plecare, în 1986, $\operatorname{Turcan}^{27}$ susține că este posibil să fi existat o comunitate relativ stabilă de orfici la Cumae. Acestă părere a fost fost contestată de Pailler ${ }^{28}$ în anul 1995, deşi acesta nu aducea multe argumente convingătoare.

O inscripție de la Torre Nova, datând din secolul al II-lea al erei noastre, aminteşte de o grupare bahică organizată într-o ierarhie, care este mult mai potrivită pentru lumea romană. Dar cine sunt aceşti oameni îngropați cu un papirus în mână, care detestau sângele (practicile sacrificiale), scriau cosmogonii şi visau poveşti bizare

\footnotetext{
${ }^{27}$ Robert Turcan, L'âme oiseau et l'eschatologie orphique, „Revue de l'histoire des religions" nr. 155, 1959, pp. 33-40.

${ }^{28}$ Jean-Marie Pailler, Bacchus: figures et pouvoirs, Paris, 1995.
} 
despre naşterea zeilor? Ce dorea Orfeu şi descântecele tăcute? De fapt, au căutat un singur scop: sănătatea. Ei doreau să se vindece şi au căutat să fugă de lume ${ }^{29}$. Orficii au renunțat la tot pentru a năzui la starea de ființă divină ${ }^{30}$. Ei s-au supus pentru aceasta unor tehnici de purificare pentru a se separa de alții, tăind orice legătură cu lumea şi cu orice subiect care este supus morții şi pângăririi.

\section{Orfismul -mod de viață}

În lucrarea „Legile”, Platon sintetizează regulile stricte şi modul de viață al orficilor, printre care aminteşte abstinența de la toate felurile de carne, oferindu-le şi zeilor numai prăjituri sau fructe înmuiate în miere, deoarece se considera lipsit de cuviință şi necurat să mănânci carne şi să pătezi cu sânge altarele zeilor. Jertfele sângeroase au fost baza rituală a religiei de stat şi, datorită acestor reguli, orfismul a fost mutat în afara polis-ului. După cum menționează şi Herodot în ale sale ,Istorii", extazul a fost un important aspect al modului de viață orfic. Despre acest mod de viață ne aminteşte şi Platon, care relatează că mulți au eşuat pe această cale, care nu era uşoară: „Mulți sunt purtători de nuia, dar puțini bacchoi”’31. Este posibil ca aceştia să fi purtat nuia pentru flagelare, voind să domolească trupul sau să stârnească sensibilizare spirituală.

Modul de viață orfic implica o viață fără compromisuri, iar renunțarea era exprimată prin condamnarea atât a jertfelor sângeroase, cât şi a legăturii sociale stabilite în întregul polis, care promova obiceiul ca atunci când un animal era sacrificat în templu, carnea să fie împărțită între participanți.

Orfismul nu a încercat niciodată o reformă politică, nici nu a avut în vedere o alternativă statală sau a politicii cultului. Găsirea unui regim vegetarian a însemnat o pregustare a vieții printre zei. Asupra sacrificiului, zeii au constituit un singur tot, în care atât

\footnotetext{
$29 * * *$, Encyclopedia...op. cit., p. 459.

${ }^{30}$ André Boulanger, op. cit., p. 30.

${ }^{31}$ G.R.S. Mead, op. cit., p. 48.
} 
politica, cât şi societatea şi religia erau într-un echilibru perfect ${ }^{32}$. Când orficii au renunțat la majoritatea zeilor greci, ei au început să aibă întrebări privind tot ceea ce cuprinde viața socială, inclusiv politeismul, în măsura în care acesta a pătruns în societate şi a jucat un rol integral în politică. Dar, chiar şi aşa, orfismul nu a avut credibilitate în politeismul altora, pe care însă nu 1-a respins în întregime. În cazul în care ar fi făcut aceasta, era în pericol de a-şi reteza el însuşi legăturile de comunicare cu cei care erau pe punctul de a se vindeca. Multitudinea zeilor era inevitabilă. Prin urmare, orficii au trebuit să regândească divinitatea şi să o transforme într-o forță divină ordonatoare şi să elaboreze o alternativă genealogică a puterilor.

O parte din doctrina orfică este asemănătoare cu cea a pitagoreicilor. Există o părere general valabilă a cercetătorilor asupra purității vieții în ce priveşte cele două comunități. În ambele era recomandată castitatea şi cumpătarea. Îndemnul la castitate era dat familiştilor, doar după ce căsătoriții aveau odrasle şi, astfel, se perpetua viața. Era aspru condamnat adulterul. „Cuvântul unui pitagorician era şi angajamentul lui. Iar în cele din urmă un bărbat trebuie să trăiască în aşa fel încât să fie totdeauna pregătit să moară"(Hyppolytus, Philos. VI ${ }^{33}$ ). Aceste lucruri țin de disciplina exterioară, însă pentru ambele comunități exista un mod anume de disciplină interioară, care era socotită de cei care nu erau incluşi în tagmă, ca fiind secretă. De multe ori, prin disciplina exterioară se ajungea la disciplinarea simțurilor şi a facultăților mentale.

O altă mărturie despre modul de viaţă orfic ne este dat de Euripide. În lucrarea Hipolit, personajul principal cu acelaşi nume este catalogat de către Thezeu un inițiat al misterelor orfice. El doreşte să fie pur ca un zeu, nu ca un muritor, fapt ce reiese din versurile 948-950. Însă Thezeu îi dezaprobă acest ideal al lui Hipolit, care îşi stabilea un regim din care refuza orice hrană de origine animală. Este posibil să fi făcut Euripide din Hipolit un adept al

$32 * * *$, Encyclopedia ...op. cit., p. 459.

${ }^{33}$ G.R.S. Mead, op. cit., p. 187. 
orfismului? André Boulanger este de părere că poetul tragic i-a oferit personajului său un model de comportament şi viață orfică $\breve{a}^{34}$, chiar dacă acesta a fost acuzat că ar fi un credincios prefăcut. O informație legată de orfism mai găsim în parabaza Păsările a lui Aristofan, în care autorul prezintă o parodie a cosmogoniei orfice. Guthrie K.W.C., este de părere că Aristofan a amestecat mai multe povestiri pe care apoi le-a parodiat, încercând să dea naştere chiar la o teogonie într-un notă personală. Iar într-o altă lucrare a

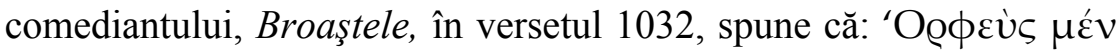

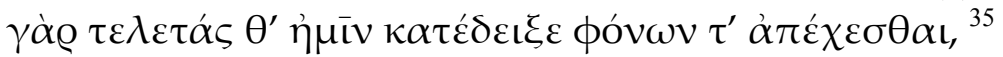

\section{Disciplina interioară}

La intrarea în aceste comunități, neofitul îşi dăruia bunurile în scopul comun al grupului. Îmbrăcămintea era simplă, nepurtând niciodată haine de piele. Pentru a fi acceptat era necesară o bună reputație. Pentru novici, exista o perioadă de probă caracterizată prin diferite ritualuri de purificare, înfrânări, asceză, pe care trebuiau să le urmeze sau să nu le încalce. Pentru a fi acceptat în grup şi dobândirea cunoaşterii esoterice era necesară urmarea a trei etape. Prima consta în aceea că timp de doi ani trebuia să asculte fără să întrebe asupra celor predate, având ca scop dedicarea totală asupra memorizării,

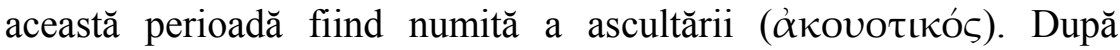
această perioadă, intră în a doua etapă, numită a matematicii ( $\mu \alpha \theta \eta \mu \alpha \tau \iota \kappa o i ́)$. În această perioadă se învăţa sensul matematicii şi geometriei, dar şi al muzicii, precum şi semnificaţia naturii numărului şi a formei. Astfel, apare întrebarea: de ce se punea atât de mult accent pe matematică? În fapt, ce este matematica la origine? După cum mărturiseşte Proclus: „,pitagoreicii credeau că întregul obiect al mathesisu-lui era aducera aminte (adică recuperarea cunoaşterii pierdute, plecând de la ipoteza că sufletul este cu adevărat

\footnotetext{
${ }^{34}$ André Boulanger, op. cit., p. 44.

${ }^{35}$ Aristofan, Broaştele, versetul 1032: „Orfeu ne-a descoperit misterele de inițiere şi totodată cum să ne ferim de a săvârşsi omoruri"
} 
nemuritor şi, în consecință, a avut o experiență înaintea vieții curente), dar nu inserată în suflet în mod extern aşa cum fantasmele obiectelor sensibile sunt imprimate în imaginație...ci stârnită de lucrurile aparente şi exercitată interior prin puterea de raţionare convertită la ea însăşi... Mathesis este, aşadar, reminiscienţa principiilor eterne inerente sufletului, iar ştiința matematicii devine astfel cunoaşterea ce facilitează reamintirea acestor principii" ${ }^{36}$. Iar

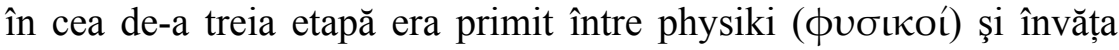
acum despre natura interioară a lucrurilor, tainele cosmogoniei şi probleme de metafizică. Acest grad era permis celor care se supuneau unei vieții ascetice şi cărora Pitagora le destăinuia din tainele învățăturii interioare. Problemele esoterice nu se notau niciodată sau nu erau scrise, ci doar memorate şi erau formate din simboluri şi axiome mistice care erau explicate. După o perioadă întreagă de cinci ani erau admişi în comunitate, atât bărbaţi cât şi femei.

\section{Sufletul este pedepsit în trup}

Pitagoreicul Filolaus, citat de Clement Alexandrinul în Stromate V, spune că: ,teologii şi iniţiaţii antici mărturisesc că sufletul este legat de corp pentru a fi pedepsit; şi că este înmormântat în trup ca în mormânt",37, iar Pitagora, citat tot de Clement Alexandrinul spune că: „orice vedem când suntem treji este moarte şi când dormim un vis" "38. În acest fel, viaţa adevărată nu este nici una dintre aceste stări. Thomas Taylor ${ }^{39}$ este de părere că anticii, prin scrierile homerice, atribuiau lui Hades unitatea sufletului cu trupul

\footnotetext{
${ }^{36}$ G.R.S. Mead, op. cit., p. 218.

37 Clement Alexandrinul, Scrieri-Stromatele, partea a II-a, în P.S.B. 5, Traducere, cuvânt înainte, note şi indici de Pr. Dumitru Fecioru, E.I.B.M.B.O.R., Bucureşti, 1982, pp. 314-322.

${ }^{38}$ Ibidem.

39 Thomas Taylor, Eleusian and bacchic mysteries,Edited, with introductin, notes, emandations and glossary by Alexnder M.D.Wilder,Fourth edition, NewYork, 1891, p. 238.
} 
actual. Această unire era socotită dezastroasă, însă de ea se putea scăpa prin filozofie. Pedeapsa lui de aici înainte nu era altceva decât continuarea stării sale pământeşti şi o trecere de la somn la somn şi de la vis la vis, iar această stare este simbolizată ocult prin reprezentarea misterelor inferioare.

Omul este supus unei legi a naturii şi nu se poate elibera din temnița trupului nici măcar prin sinucidere, pentru că sufletul impur este supus unei „roți a destinului”. Prin ieşirea din temnița trupului, sufletul este silit de o necesitate ce îi este ursită - aceea de a se reîncarna într-un alt trup, fie şi de animal, acest ciclu de naşteri fiind veşnic pentru cei ce sunt neiniţiaţi. Pentru orfici, era interzisă consumarea mâncării de origine animală tocmai pentru că transmigrația sufletului cuprinde respectul pentru fiecare ființă din univers $^{40}$. Adepții orfismului ar fi susținut nevoia de mai multe vieți terestre pentru a ajunge la purificarea deplină.

Epoca în care apare acestă idee corespunde perioadei în care este acceptată ideea de răspundere individuală, în care se credea că sufletul după moarte ajunge să fie judecat, iar în funcție de hotărârea dată de tribunal sufletul ajunge să fie chinuit. Chinurile, pentru cei care aveau păcate de ispăşit şi pentru cei care nu erau purificați deplin, nu erau veşnice.

Pentru cei care au aderat şi şi-au însuşit virtuțile vieții orfice, sufletul este eliberat din chinga trupului pentru totdeauna şi poate să se îndrepte spre sălaşurile divine, bucurându-se de fericirea eternă. $\mathrm{Cu}$ toate acestea, nici acest drum spre bucuria veşnică nu este lipsit de încercări şi primejdii. Iniţiatul are de parcurs un itinerar asupra cuvintelor pe care trebuie să le rostească în drumul prin infern. Aceste formule precise de trecere s-au păstrat şi în inscripțiile de pe foiţele de aur descoperite în sudul Italiei şi Creta şi care sunt un ,îndeptar” pentru lumea cealaltă.

$\mathrm{Cu}$ toate detaliile urmate de cel iniţiat, în lumea de dincolo paradisul orficeste vag prezentat. Este posibil ca paradisul orfic să fie o câmpie sacră închinată Persefonei sau partea superioară a cerului

${ }^{40}$ André Boulanger, op. cit., p. 30. 
unde sunt aştrii, după cum amintesc inscripțile de pe foițele de aur ${ }^{41}$. Aceste inscripții au structura unui ghid exact pentru lumea cealaltă. $\mathrm{Cu}$ toate acestea, nu putem să catalogăm expres aceste texte ca fiind orfice, tocmai pentru că ele nu depăşesc secolul al III-lea î.d.Hr. Una dintre aceste inscripții îl previne cel mort că atunci când va ajunge la răspântia drumului infernal va afla un izvor, iar lângă aceasta un mare chiparos alb. Să fie cu băgare de seamă că nu trebuie să bea din acest izvor chiar dacă va fi însetat, pentru că este izvorul Uitării. Să ia aminte să meargă în partea dreaptă şi să bea din lacul Amintirii şi să le spună paznicilor: „Sunt fiul Pământului şi al cerului înstelat. Sunt dintr-o seminţie cerească. Să ştiţi şi voi aceasta! Dar setea mă usucă şi pier. Daţi-mi să beau de îndată din apa proaspătă care curge din lacul Amintirii” După aceste cuvinte, paznicii îl vor lăsa să bea din aceasta, iar sufletul său va putea merge ,alături de ceilalți eroi”. O altă tăbliță are un discurs interesant în care iniţiatul se adresează zeiței astfel: „Am suferit pedeapsa ce se cuvenea faptelor mele nedrepte...Iar acum vin la strălucita Persefona să o rog să mă trimită în sălaşul sfinţilor”, la care răspunsul zeiței: „Salutare ție, care ai îndurat suferința pe care nicicând înainte nu ai suferit-o... salutare, salutare, salutare ție. Mergi pe drumul din dreapta către câmpiile sacre şi pădurile Persefonei”. Pe o altă tăbliță, iniţiatul trebuie să se adreseze zeilor din infern astfel: ,vin din tagma celor neprihăniţi, o, preacurată stăpână a infernului, Eucles, Eubuleus şi voi ceilalţi zei nemuritori. Căci sunt mîndru să fac parte din neamul vostru, preafericită. Însă m-a doborât destinul şi ceilalţi zei nemuritori... Am ieşit din ciclul suferinţelor grele şi al durerilor şi m-am avântat cu iuțeală către coroana râvnită. Mi-am aflat adăpost la sânul doamnei, regină a infernului”. La care i se răspundea: „O, norocosule, o, preafericitule! Din om, cum erai, ai devenit zeu”. Iar iniţiatul răspundea: „Ied, am căzut în lapte”, însă nu putem pătrunde sensul acestei ultime afirmații.

${ }^{41}$ Dintre cele mai importante culegeri de texte de acest fel este importantă de amintit: D. Comparetti, Laminette orfiche, Florența, 1910; A. Olivieri, Lamellae aurae orphicae, Bonn, 1915; Otto Kern, op cit., 1922. 


\section{Câteva puncte caracteristice orfismului}

În gândirea homerică este străină acceptarea înrudirii dintre ființele vii cu divinul, iar asupra psyché-ului, nu se concepea o nemurire a lui, ci o existență diafană în lumea de dincolo. În contradicție cu acest sistem de gândire, credința orfică aduce o nouă abordarea a vieții. În acest fel, credința orfică susține nemurirea sufletului bazată pe mitul pruncului zeu Dionysos şi omofagia titanilor. Ceea ce este de rezonanță în toată această capodoperă transmisă sub denumirea lui Orfeu este că, înainte de a fi acestă jertfă, nu existau seminții diferite. Tot ceea ce se petrecea era în cadrele nemuririi, fapt ce aduce aminte de existența paradisiacă, în care legătura omului cu Dumnezeu era directă.

Există posibilitatea ca omul să plătească resentimentele naturii „titanice” prin acceptarea unui „mod de viață orfic” ( $\beta 10 \varsigma$ орфєıкı) prin care să se amelioreze durerile Persefonei, ca interzicerea de a mânca carne şi de a aduce sacrificii, abluțiuni şi diferite norme de abstinență şi aplicarea unei diete exclusiv vegetariene. Prin acest fel de viețuire păstrat zilnic pe tot parcursul vieții se dobândeşte evsevia, care primeşte un nou conţinut, acela al cucerniciei. Prin aceasta, crima primordială nu va mai avea caracter anamnetic, pentru că este interzisă, ci o asceză care să îl pună în legătură directă cu divinitatea şi viețuirea alături de el.

Pângărirea la care este condamnat omul nu ține de el, ea un fapt supraomenesc. Omul nu are calitatea de „păcătos originar”, însă deoarece răul este o calitate moştenită, viaţa orfică devine în acest fel o viață de ispăşire. Oricine doreşte să se sustragă ciclului naşterilor şi alterării şi a se uni cu divinul trebuie să accepte viața orfică. Însă, cei care nu vor ține cont de toate aceste prescrieri vor ajunge la reîncarnare, degenerând până la reîncarnări în animale. În acest fel, cultul orfic capătă forma unei detaşări, a unui mod de viață înstrăinat de riturile de sacrificiu ale religiozității civice, care acceptă şi susține ritualurile sângeroase. Orfismul este un răspuns împotriva vieții superficiale civice şi a sacrificiilor. 
Mitul orfic al lui Dionysos nu are nici o legătură cu mitul lui Osiris, deşi aproape de la început s-a crezut că legenda morții zeului orfic ar fi de fapt copia mitului lui Osiris. (De acest lucru ar fi fost de părere şi Herodot în ale sale Istorii II, 42 şi 144; dar şi Diodor I, 11, 3). Mitul egiptean face să răsară viață din moarte, cel grec scufundă însă partea divină în trup.

În secolele V-IV î.d.Hr., care aparțin perioadei clasice, apar, după cum aminteşte Platon, mulți şarlatani (agurtai), prezicători (manteis) cu multe cărţi ale lui Orfeu. Ei îşi trag numele de la marele cântăreț, şi, pentru o mai bună reputație, umblă pe la casele celor bogați, dar şi prin cetăţi, pentru a-i păcăli pe oameni că prin incantații (epoidai) vor obține purificarea şi eliberarea de greșelile săvârşite. În piesa lui Euripide, Hippolit 954, autorul condamnă acid toate aceste scrieri încâlcite (pollon grammaton kapnus) care îi orbesc pe toți cei care îl iau pe Orfeu ca patron al lor ${ }^{42}$. Din toată această perioadă trebuie să amintim că orice mişcare cu caracter soteriologic, gnostic sau ascetic provoacă tot atâtea pseudo-morfoze dar şi inițieri pentru cei naivi. Toate atacurile din această perioadă relevă faptul că orfismul a avut o mare trecere pentru un anumit grup şi un anumit public şi, de asemenea, în această perioadă s-a schimbat centrul de greutate pe un caracter al exprimării scrise, tendință care este capabilă să ofere o cultură pseudo-religioasă.

Orfismul şi-a manifestat influența asupra mentalității religioase greceşti în două domenii. Primul a fost cel al pietăţii populare, întrucât orfismul a susținut o nelinişte asupra practicilor superstițioase pentru cei obsedați de grija întinărilor şi a bolilor. Teofrast, portretizând imaginea ,suprestițiosului”, îl prezintă ca ducându-se lunar să-şi împrospăteze inițierea alături de ceilalți membri ai familiei, consultă orpheotelestai. Pe aceştia, Platon îi descrie ca fiind nişte preoți ghicitori ambulanți, care se pretind a fi nişte cunoscători în ştiința purificării şi a inițierii (katarmoi, teletai) atât pentru cei vii cât şi pentru cei morți, în schimbul unei sume de bani. Aceşti preoți de la periferia societății, rătăceau din cetate în

${ }^{42}$ Reynal Sorel, op. cit., pp. 9-14. 
cetate şi susțineau ştiinţa unor rituri secrete şi a incantaţiilor dobândite din opera lui Orfeu şi Musaios, care de fapt exploatau credulitatea publicului.

Cel de-al doilea nivel, a fost asupra scrierile orfice. Acestea au fost alături de alte scrieri ale timpului un curent care a modificat cadrele experienței religioase şi care a schimbat cadrele vieții religioase. În această privință, orfismul se înscrie alături de pitagoreism în grupa de personaje ieşite din comun prin dobândirea în timp a titulaturii de „oameni divini”, care, prin prestigiul lor au influențat viața cetăţilor, încă din secolul al VI -lea î.d.Hr., şi despre care s-a spus uneori că ar fi făcând parte din aşa numitul ,şamanism grec" ${ }^{\prime 3}$.

\section{Legăturile şi tangențele orfismului cu creştinismul}

Chiar dacă orfismul a fost disprețuit, în general în perioada clasică, de scriitori mai apropiați de religia statală, unii autori au fost interesaţi de anumite aspecte ale mesajului lor. Astfel de autori ca Parmenide şi Empedecle, dar mai presus de aceştia pitagoreicii şi Platon, precum şi poeți lirici cum ar fi Pindar, păreau să ştie şi să accepte anumite caracteristici ale mesajului orfic. Plutarh susține că ar fi fost iniţiat în astfel de taine şi menționează mai multe doctrine orfice. Influența orfică este prezentă şi în neoplatonism şi a continuat până în secolul V şi VI după Hristos. De asemenea, există urme ale orfismului în unele papirusuri greceşti, dar şi în cultul mithraic. În aşa numitul Testament al lui $\mathrm{Orfeu}^{44}$, care dezvăluie o influenţă orfică asupra evreilor elenizați şi asupra apariției creştinismului apar două atitudini contradictorii faţă de orfism. Uneori, creştinii evidenţiază caracteristicile comune între orfici şi credincioşii creştini, pentru a face ca noul mesaj să fie mai uşor de primit de către păgâni. Orfeu a fost reprezentat la începutul creştinismului pe sarcofage şi este identificat cu păstorul cel bun în arta catacombelor. Primii

\footnotetext{
${ }^{43}$ Jean P. Vernant, Mythe et pensée chez les Grecs, Paris, 1965, pp. 91-93. $44 * * *$, Encyclopedia...op. cit., p. 460.
} 
creştini au respins direct mesajul orfic datorită faptelor pe care le conţinea, precum incestul, castrarea zeilor, monştrii malefici, etc.

Au existat discuții între diferiţi cercetători, ca Mircea Eliade şi Vittorio Macchioro, care au susținut influențarea creştinismului de către orfism. Aceştia pornesc de la ideea că Tarsul Ciliciei, locul de proveniență a Sfântului Apostol Pavel, era un oraş cu un puternic avânt sincretist, unde îşi aveau templele multe culturi de mistere. Cei doi autori susțin că Apostolul Pavel ar fi fost influențat de cultul orfic, care avea o mare răspândire în acele locuri în primul secol creştin. Acest lucru este limpede confirmat, susțin cei doi cercetători, în Epistola către Romani, unde Sfântul Apostol Pavel aminteşte de moartea credinciosului ,împreună cu Hristos” (Romani 6, 8) şi înviere ,pentru Dumnezeu, în Hristos Iisus” (Romani 6, 11) pentru viaţa veşnică. În acest fel, cercetătorii amintiţi de mai sus au asemănat orfismul cu creştinismul prin preluarea ideii morții şi a vieții alături de divinitate. Însă, de cealaltă parte a cercetării, mai mulți cercetători precum I.G. Coman, A. Boulanger, W.K.C. Guthrie şi alţii au arătat diferența esenţială între creştinism şi orfism. Printre cele mai importante diferențe este şi aceea că moartea Mântuitorului Hristos este o jertfă conştientă şi voluntară, pe când moartea lui Euridice din cântecul orfic este neputința de a face ascultare continuă de glasul divinității pentru salvarea celui iubit.

În perioada creştinismului primar, artiştii creştini ai catacombelor îl gravează pe Orfeu înconjurat de animale sălbatice, care stau supuse sub acordul lirei sale. Orfeu dobândeşte o nuanţă centripetă care transformă sălbăticia, sub puterea lirei, într-o adunare potolită şi atentă, care i-a impresionat pe primii creştini ${ }^{45}$. Această influență este doar colaterală, pentru că punctele de doctrină orfice vin în contradicție cu teologia paulină care susține că sufletul omenesc nu este de origine divină, ci este sediul harului şi al inspiraţiei lui Dumnezeu. Apostolul Pavel, iar mai apoi Tradiţia Bisericii au susținut permanent dobândirea harului divin prin care se creează o substituție de persoane: „Nu mai trăiesc eu, ci Hristos

${ }^{45}$ Reynal Sorel, op. cit., p. 154. 
trăieşte în mine" (Galateni 2, 20), în timp ce adepții lui Orfeu regăseau divinul prin aplecare asupra lor înşişi.

„Dacă figura lui Orfeu se ridică la treapta dătătorului de cultură - abia ceva mai jos de Prometeu, dătător al focului şi cu el, a civilizației materiale -orfismul aduce înlăuntrul culturii răspunderea acesteia, nu numai de a instrui şi desfăta, dar şi de a modela oameni”, ${ }^{\prime 4}$. Orfismul nu a fost o mare religie cu o influență majoră în istoria culturii, dar nu a fost nici doar o simplă etică. Pe tot parcursul existenței sale, orfismul a căutat să fie un exercițiu spiritual fără de care cultura riscă să devină o practică sterilă şi neînțeleasă.

\section{Bibliografie:}

1. ***, Encyclopedia of religion, Second edition, Tome 10, New York, 2005;

2. ***, Fragmentele presocraticilor, Traducere integrală după ediția Diels-Kranz cu introducere şi note de Simina Noica şi Constantin Noica, Volumul I, Editura Junimea, Iaşi, 1974;

3. Boulanger, André, Orphee: rapports de l'orphisme et $d u$ christianisme, Paris, 1925;

4. Brisson, Luc, Orphéé et l'orphisme dans l'antiquité gréco-roumaine, Aldreshot, U.K., 1995;

5. Calame, Claude, Philippe Borgeaud, Andre Hurst, L'Orphisme et ses écritures: nouvelles recherches, „Revue de l'histoire des religions”, nr. 219, 2002, pp. 379-515;

6. Clement, Alexandrinul, Scrieri-Stromatele, partea a II-a, în P.S.B. 5, Traducere, cuvânt înainte, note şi indici de Pr. Dumitru Fecioru, E.I.B.M.B.O.R., Bucureşti, 1982;

7. Eliade M., Istoria credințelor şi ideilor religioase, ediția II, Volumele II, Traducere de Cezar Baltag, Editura Ştiințifică şi enciclopedică, Bucureşti, 1986;

8. Guthrie, W. K. C., Orpheus and the greek religion, Second edition, London, 1952;

9. Mead, George R.S., Orpheus, Second edition, Kessinger Publishing, 2010;

$46 * * *$, Fragmentele presocraticilor...op. cit., pp. 23-24. 
10. Reynal, Sorel, Orphée et l'orphisme, Presses Universitaires de France, Paris, 1995;

11. Taylor, Thomas, Eleusian and bacchic mysteries,Edited, with introductin, notes, emandations and glossary by Alexnder M.D.Wilder,Fourth edition, New-York, 1891;

12. Turcan, Robert, L'âme oiseau et l'eschatologie orphique, „Revue de l'histoire des religions" nr. 155, 1959, pp. 33-40;

13. Vernant, Jean P., Mythe et pensée chez les Grecs, Paris, 1965; 